\title{
The effect of lead on the phytochemistry of Tithonia diversifolia exposed to roadside automotive pollution or grown in pots of Pb-supplemented soil
}

\author{
Elizabeth Olivares
}

Centro de Ecología, Instituto Venezolano de Investigaciones Cientificas, Apartado 21827, Caracas 1020 A, Venezuela; eolivare@oikos.ivic.ve Received: 20/07/2003, Accepted: 16/10/2003

Tithonia diversifolia, a ruderal weedy species utilized in agroforestry, is widely distributed in the tropics, often being found in wasteland, margins of polluted city rivers and roadsides. The objective of this study was to compare plants sampled at a light and heavy traffic roadside for metal concentration and foliar compounds which may be related to senescence and/or detoxification of metals. The field survey was followed by an experiment in pots of $\mathrm{Pb}$-acetate-supplemented soil to verify if the same response is obtained under controlled conditions with regard to $\mathrm{Pb}$. The concentration of $\mathrm{Pb}$ in leaves and roots of plants sampled at a heavy traffic roadside was higher than in samples from a light traffic site. The content of $\mathrm{Cr}, \mathrm{Al}, \mathrm{Fe}, \mathrm{Cu}$ and $\mathrm{Ni}$ was also higher in leaves but not of roots in plants from the polluted site. No significant differences were found in the concentrations of chlorophyll, carotenoids, UV-absorbing compounds and proteins, nor in the chlorophyll $a / b$ ratio and lipid peroxidation of leaves collected at both sites. On the other hand, $\mathrm{Pb}$-contaminated leaves and roots showed higher acid phosphatase activity while the foliar nitrate reductase activity and specific leaf mass were lower. An increase of leaf phenol concentration, thought to be involved in the detoxification of metals, was observed in the polluted field plants and in roots in the pot experiment, where $\mathrm{Pb}$-acetate was supplied to the soil, but the changes observed in acid phosphatase and specific leaf mass in the field were not found in the pot experiment.

Key words: Asteraceae, metals, Mexican sunflower, phenols, pollution, weeds.

Efeito do chumbo na fitoquímica de Tithonia diversifolia exposta à poluição de rodovia ou crescidas em solo suplementado com chumbo: Tithonia diversifolia, uma espécie ruderal utilizada em sistemas agroflorestais, amplamente distribuída nos trópicos, é freqüentemente encontrada em locais de descarte, margens de rios poluídos próximos a cidades e ao longo de rodovias. O objetivo deste estudo foi comparar plantas coletadas de rodovias com pouco e com intenso tráfego em relação à concentração de metais e compostos foliares que podem estar relacionados à senescência e/ou à destoxificação de metais. Também fez-se um experimento com vasos contendo solo suplementado com chumbo para verificar se a mesma resposta é obtida sob condições controladas usando esse metal. A concentração de $\mathrm{Pb}$ nas folhas e raízes de plantas amostradas em rodovia de tráfego intenso foi maior que nas amostras de rodovia de pouco tráfego. As concentrações de $\mathrm{Cr}, \mathrm{Al}, \mathrm{Fe}, \mathrm{Cu}$ e Ni foram maiores nas folhas, mas não nas raízes de plantas da rodovia de tráfego intenso. Não houve diferença significativa nos conteúdos de clorofila, carotenóides, compostos absorvendo no UV e proteínas, como também na razão clorofilas $a / b$ e peroxidação de lipídeos das folhas coletadas em ambas as rodovias. Por outro lado, folhas de plantas contaminadas com $\mathrm{Pb}$ mostraram maior atividade de fosfatase ácida, enquanto a atividade foliar da redutase do nitrato e a massa foliar específica foram menores. Aumento na concentração de fenóis, o que se pensa estar envolvido na destoxificação de metais, foi observado nas plantas coletadas na rodovia de tráfego pesado e nas raízes do experimento com vasos, no qual $\mathrm{Pb}$ foi adicionado ao solo. Todavia, as alterações de fosfatase ácida e massa foliar específica não foram observadas nesse experimento.

Palavras-chave: Asteraceae, fenóis, girassol mexicano, metais, plantas daninhas, poluição. 


\section{INTRODUCTION}

Mexican sunflower, Tithonia diversifolia is widely distributed in the tropics, from Mexico to Brazil, and is also found in Asia and Africa, where it has been introduced in view of its multiple uses, for example, as animal forage, green fertilizer, a natural insecticide, a honey-plant and an ornamental shrub (Rios, 1999). The species enhances the availability of $\mathrm{P}$ to crops, which led to its recommendation for biomass transfer technologies in Kenya (George et al., 2002 a, b). However, it behaves as an aggressive weed with high invasive capacity in Africa (Ayeni et al., 1997). This species, adapted to a variety of ecological zones, is present in Venezuela, from montane environments in the Coastal and Andean ranges to the savanna areas, and is very common in wasteland, margins of polluted city rivers and roadsides. Studies of biochemical responses to environmental pollution of $T$. diversifolia are important, since this species is recommended in agroforestry for animal production in the tropics and is also a weed capable of inhabiting polluted sites.

García-Miragaya et al. (1981) reported strong Pb pollution in roadside soils at Caracas, Venezuela, due to heavy traffic of motor vehicles and the utilization of leaded gasoline. At present, only motor vehicles bought after the year 2000 use unleaded gasoline in Venezuela and consequentely the same or higher levels of $\mathrm{Pb}$ contamination prevail.

Lagerwerff and Specht (1970) reported that the concentrations of $\mathrm{Cd}, \mathrm{Ni}, \mathrm{Pb}$ and $\mathrm{Zn}$ in roadside soil and grass samples from several locations decreased with the distance from vehicular traffic. Contamination was related to the composition of gasoline, motor oil and automobile tires, and to roadside deposition of residues of these materials. Contamination from motor vehicle emissions within $100 \mathrm{~m}$ of the roadway has been reported in vegetation (Motto et al., 1970; Ward et al., 1975), soils (Yassoglou et al., 1987), and spider webs (Hose et al., 2002). Lead added to fuel as tetra ethyl, to act as a lubricant during combustion, is discharged into the environment in exhaust fumes largely as minute particles of inorganic $\mathrm{Pb}$ compounds and about $50 \%$ of this falls within a region of $100 \mathrm{~m}$ from the road (Mengel and Kirkby, 2001).

In the year 2000, the cumulative industrial age anthropogenic global production of $\mathrm{Pb}$ was 235 million tonnes (Han et al., 2002). According to Weiss et al. (1999) since the industrial revolution and until 1950, the main sources of $\mathrm{Pb}$ in the biosphere have been industrial activity mostly coal combustion and ferrous and non-ferrous smelting, as well as open waste incineration, whereas from 1950 onwards it has been the use of leaded gasoline. The largest $\mathrm{Pb}$ emissions into the atmosphere throughout Europe took place between 1950 and 1980 due to automotive exhausts. The marked drop in atmospheric $\mathrm{Pb}$ fluxes, recorded since the 1980s, has been attributed to the phasing out of leaded gasoline.

Diverse biochemical changes in green plants in response to $\mathrm{Pb}$ have been reported by several authors: decreases in chlorophyll content (Ewais, 1997; Xiong, 1997; Kastori et al., 1998; Fargašová, 2001), carotenoids (Fargašová, 2001), proteins (Kevresan et al., 2001), nitrate reductase activity (Singh et al., 1997; Kevresan et al., 2001), lamina and mesophyll thickness, epidermal cell size and diameter of vessels (Kovačević et al., 1999); increases in chlorophyll $a / b$ ratio (Fargašová, 2001) and concentration of phenols (Lummerzheim et al., 1995; Lavid et al., 2001 a, b). In the presence of other metals, such as $\mathrm{Al}, \mathrm{Cu}$ and $\mathrm{Cd}$, lipid peroxidation has been found to increase (Cakmark and Horst, 1991; Gallego et al., 1999; Pereira et al., 1999; Baryla et al., 2000; Hartley-Whitaker et al., 2001; Sandalio et al., 2001; Shah et al., 2001).

Thus, in metal contaminated plants we expect to find senescence symptoms, such as lower concentrations of chlorophyll, carotenoids and proteins, diminished nitrate reductase activity and increased acid phosphatase activity, lipid peroxidation and chlorophyll $a / b$ ratio compared to plants not stressed by metals. We also expect detoxification through phenols.

The objective of the present study was to evaluate metals in foliar and root material from field samples of $T$. diversifolia, collected at two sampling sites with contrasting pollution levels due to automotive traffic, as well as evaluate foliar compounds sensitive to phytotoxic concentrations of metals. The field study was followed by an experiment using pots of $\mathrm{Pb}$-acetate-supplemented soil to learn whether the parameters affected in the field also change when the plants are exposed to the same air and soil, but to a different concentration of $\mathrm{Pb}$ in the soil. This experiment was carried out in order to verify whether the parameters affected in the field were responding to $\mathrm{Pb}$.

\section{MATERIALS AND METHODS}

Plant material and sites: Tithonia diversifolia (Hemsl.) Gray (Asteraceae) was sampled in two agricultural fields near satellite towns of Caracas, Venezuela, where the plant grows wild on roadsides. The control site (Site 1) is located at $10^{\circ}$ $21^{\prime} \mathrm{N}, 66^{\circ} 56^{\prime} \mathrm{W}$, in a rural area (El Amarillo) close to the town of San Antonio, while the polluted site (Site 2) is located at $10^{\circ} 22^{\prime} \mathrm{N}, 67^{\circ} 05^{\prime} \mathrm{W}$, where automotive traffic is 
heavy because it is close to the entrance of the town of San Pedro. Soils from both sites presented a sandy clay loam texture, a $\mathrm{pH}(\mathrm{KCl})$ between 5 at Site 1 to 6 at Site 2, together with large concentrations of $\mathrm{Fe}\left(36 \mathrm{mg} \cdot \mathrm{g}^{-1}\right)$ and $\mathrm{Al}$ $\left(17 \mathrm{mg} \cdot \mathrm{g}^{-1}\right)$ in similar concentrations at both sites (Olivares et al., 2002a).

At each site, 15 whole plants of approximately $2 \mathrm{~m}$ height were collected. The plants were transported to the laboratory with their roots immersed in tap water. In the present study, T. diversifolia leaves and roots were washed before analysis, since a previous study conducted on plants exposed to highway dust showed that unwashed plant tissue had a higher $\mathrm{Pb}$ content than those analyzed after a $15 \mathrm{~min}$ wash with distilled water, indicating that $27 \%$ of the $\mathrm{Pb}$ occurred on the surface of the leaves (Isermann, 1977).

Analysis of mineral elements: The leaves and roots were dried in a ventilated oven, for approximately $78 \mathrm{~h}$ at $60^{\circ} \mathrm{C}$ to constant weight and then ground. Total nitrogen concentration was determined by the Kjeldhal method (Tecator Kjeltec Systems from Foss Tecator, Höganäs, Sweden) after digestion with sulphuric acid of the ground dry plant material.

Phosphorus was measured colorimetrically (Murphy and Riley, 1962) in the digested material by means of an UV/ visible spectrophotometer (Ultrospec 2000, Amersham Pharmacia, Cambridge, England).

For the measurement of metals ( $\mathrm{K}, \mathrm{Ca}, \mathrm{Mg}, \mathrm{Mn}, \mathrm{Cd}, \mathrm{Co}$, $\mathrm{Pb}, \mathrm{Cr}, \mathrm{Al}, \mathrm{Fe}, \mathrm{Cu}$ and $\mathrm{Ni}$ ) samples were digested in a nitricperchloric acid mixture (Miller, 1998) and analysed with an atomic absorption spectrometer (SpectrAA 55B, Varian Techtron, Victoria, Australia).

Enzymatic activities: Nitrate reductase activity (NRA) was determined in fresh tissue of leaves and roots from each site by measuring the amount of nitrite produced from nitrate; nitrite was estimated by formation of the diazonium salt after reaction of nitrite with sulphanilamide in acid medium (Lindblad and Guerrero, 1993). Acid phosphatase activity (APA) in fresh tissue of leaves and roots was determined according to Tabatabai and Bremner (1969). Activities were expressed on a dry mass basis, using the fresh mass/dry mass ratio of leaf discs taken from the same leaves used for enzyme activity determinations.

Organic compounds affected by metals and leaf specific mass: For determinations of chlorophyll and carotenoids, fresh tissue of leaves was ground in a mortar with cold $80 \%$ aqueous acetone. The concentration of chlorophyll $a+b$ and the total concentration of carotenoids were calculated according to Lichtenthaler and Wellburn (1983). The amount of UV-Babsorbing compounds was estimated in fresh leaf tissue by measuring the absorbance at $300 \mathrm{~nm}$ in acidified methanol solutions (Day and Demchik, 1996). Total phenols were measured colorimetrically in ethanol extracts of ground dried leaves, using the Folin-Ciocalteu method (Amorim et al., 1977); values were standardized against chlorogenic acid. Lipid peroxidation in fresh tissue of leaves was measured by the formation of a 2-thiobarbituric acid (TBA)-malondialdeyde (MDA) complex (van Hasselt et al., 1996). Water-soluble proteins were determined according to Bradford (1976).

Specific leaf mass (SLM) was calculated from the dry mass expressed per unit area using four leaf discs $\left(1.41 \mathrm{~cm}^{2}\right.$ diameter) dried in a microwave oven for approximately 15 min to constant weight. SLM corresponds to the inverse of specific leaf area (SLA) or ratio of leaf area to leaf dry mass, dimension quotients were introduced by Stocker in 1931 and Müller-Stoll in 1947 (Medina et al., 1990).

Pot experiment with Pb-supplemented soil: Twenty young plants were selected in the field according to their uniformity in size ( $0.5 \mathrm{~m}$ height $)$ and were transplanted with their native soil to pots ( $2 \mathrm{~kg}$ soil capacity) and kept in the grounds of the "Instituto Venezolano de Investigaciones Científicas" (I.V.I.C.), a site with low traffic and low $\mathrm{Pb}\left(0.41 \mu \mathrm{g} . \mathrm{m}^{-3}\right)$ in the air (Escalona and Sanhueza, 1981). The soil also presented a low $\mathrm{Pb}$ concentration (42 to $64 \mathrm{mg} \cdot \mathrm{kg}^{-1}$ ). The soil was described in Olivares et al. (2002 b). The pots were supplemented with solutions of analytical grade $\mathrm{Pb}$-acetate at 21 and 29 days after transplantation $(1$ g.kg-1 soil at each time). During the 3 weeks without $\mathrm{Pb}$, the plants become adapted to the pot condition. Lead was added in two progressive sessions in order to increase the probability of $\mathrm{Pb}$ incorporation through roots. Pb-acetate was used by Ewais (1997), Xiong (1997) and Singh et al. (1997/98). A gradient was

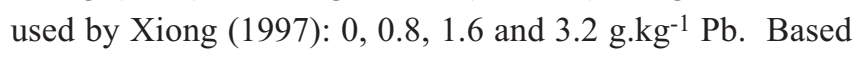
on this gradient two treatments were selected, 0 and 2 g. kg-1 soil. The plants were watered daily and care was taken that no water was lost from the dishes under the pots. The plants were maintained under natural conditions of light and air temperature and humidity. The maximal radiation in the greenhouse as reported by Suarez (2000) was $1550 \pm 370 \mathrm{mmol} \cdot \mathrm{m}^{-2} \cdot \mathrm{s}^{-1}$, with daily temperatures of $30.5 \pm 3.4^{\circ} \mathrm{C}$ during the day and $16.3 \pm 2.0^{\circ} \mathrm{C}$ during the night and with a relative humidity from 50 to $78 \%$. 
After 34 days of the first metal application measurements were made of the concentration of phenols, APA of leaves and roots and SLM (variables that suffer changes in response to $\mathrm{Pb}$ in the field plants) using 5 plants selected randomly from the 10 plants in each treatment.

Statistical analysis: Student's t-test was used for mean comparisons using the software Sigma plot 2001 (V7.0). Regression analysis was used for the APA and $\mathrm{Pb}$ data. Two-way ANOVA was carried out to compare the total concentration of mineral elements and enzymatic activities in T. diversifolia grown in the field at two sites (with light and heavy automotive traffic) and between two organs (leaves and roots) using the software Statistica 6.0 (Statsoft Inc.). The same analysis was done to compare levels of Pb, phenols, APA and SLM in plants grown in pots between two treatments (with or without $\mathrm{Pb}$-acetate) and two organs. One-way ANOVA was carried out to compare biochemical parameters and SLM in leaves with different foliar $\mathrm{Pb}$ content from plants grown in the field.

\section{RESULTS}

Analysis of mineral elements in leaves and roots: In leaves, the content of heavy metals ( $\mathrm{Pb}, \mathrm{Cr}, \mathrm{Al}, \mathrm{Fe}, \mathrm{Cu}$ and $\mathrm{Ni}$ ) was higher in samples from the polluted Site 2 than in those from the control Site 1 . The $\mathrm{Pb}$ concentration was found to be 15 times higher for Site 2 than Site 1 (table 1). In roots, higher values were also found for $\mathrm{Pb}$ at Site 2, while the other metals occurred in similar or lower amounts in samples from Site 2 compared with Site 1 . The metals Co and Cd were not detected, the detection limits being $0.05 \mu \mathrm{g} . \mathrm{g}^{-1}$ for Co and $0.02 \mu \mathrm{g} . \mathrm{g}^{-1}$ for $\mathrm{Cd}$.

Roots and leaves from Site 2 showed higher concentrations of $\mathrm{P}, \mathrm{K}$ and $\mathrm{Ca}$ than those from the less polluted Site 1 (table 1). The same relationship between sites held for Mn in leaves, and for $\mathrm{Zn}, \mathrm{N}$ and $\mathrm{Mg}$ in roots. The ANOVA showed differences between sites in the mineral elements except for $\mathrm{Fe}, \mathrm{Mn}$ and N, and between organs except for K.

Enzymatic activities: The NRA was lower in leaves from Site 2 as compared with those from Site 1 but was similar in roots from both sites (table 1). APA was higher in both leaves and roots of the more polluted Site 2, where higher values of $P$ were also found. The following regressions were found between APA and P concentrations: $\mathrm{y}=0.11 \mathrm{x}+1.84, \mathrm{r}^{2}=0.60$ (roots and leaves); $\mathrm{y}=0.07 \mathrm{x}+0.28, \mathrm{r}^{2}=0.73$ (leaves); and $\mathrm{y}$
$=0.07 \mathrm{x}-0.03, \mathrm{r}^{2}=0.57$ (roots). The ANOVA showed significant differences between sites and organs.

Organic compounds affected by metals and leaf specific mass: Chlorophyll, chlorophyll $a / b$ ratio, carotenoids, compounds absorbing at $300 \mathrm{~nm}$ such as flavonoids and proteins, lipid peroxidation and water-soluble proteins were similar at both sites, while the concentration of phenols was higher and SLM was lower for Site 2 (table 2). The t-test and one way ANOVA showed similar results.

Pot experiment with Pb-supplemented soil: Young plants transplanted to pots with $\mathrm{Pb}$-acetate in the soil showed a highly significant increase in phenol concentration in roots compared to the controls without Pb-acetate (table 3). The concentration of lead in roots was very high and higher than in leaves, whereas in the field, where the main source of $\mathrm{Pb}$ would be from the emissions of motor vehicles, a higher concentration was observed in leaves than in roots. For the plants from the greenhouse experiment there were no significant differences in SLM and the APA did not increase in Pb-contaminated plants in contrast to the field plants, where these responses may depend on multiple factors rather than $\mathrm{Pb}$ alone. However, a very highly significant increase of phenols was observed in $\mathrm{Pb}$-contaminated roots.

The ANOVA showed differences between treatments and organs for $\mathrm{Pb}$. The difference in phenol concentration in roots was highly significant for both treatments but not in leaves. The two-way ANOVA therefore did not show differences between treatments because it includes both organs.

\section{DISCUSSION}

Analysis of mineral elements in leaves and roots: The concentration of $\mathrm{Pb}$ in leaves from heavy traffic roadside sites found in this study is higher than those reported by Ross (1994) as typical values for $\mathrm{Pb}$-contaminated plants (30-300 $\left.\mu \mathrm{g} . \mathrm{g}^{-1}\right)$. Mengel and Kikby (2001) reported values of $50 \mu \mathrm{g} \cdot \mathrm{g}^{-1}$ $\mathrm{Pb}$ in vegetation at the side of the road in motorway areas, with roots being very little affected, but only 2 to $3 \mu \mathrm{g} \cdot \mathrm{g}^{-1} \mathrm{~Pb}$ at a distance of $150 \mathrm{~m}$ from the motorway.

The concentrations of $\mathrm{Cr}, \mathrm{Cu}$ and $\mathrm{Ni}$ in leaves from polluted Site 2 were at the lower limit of the range typical of contaminated plants, whereas at Site 1 leaves showed concentrations of $\mathrm{Cr}, \mathrm{Cu}$ and $\mathrm{Ni}$ below this range.

T. diversifolia from Site 2 had a higher concentration of $\mathrm{Pb}$ in leaves than in roots. This may be explained by the fact that there are two major pathways for the incorporation of 
Table 1. Mineral concentrations, nitrate reductase activity (NRA) and acid phosphatase activity (APA) in leaves and roots of T. diversifolia from two sites: with light (site 1) or heavy (site 2) automotive traffic.

\begin{tabular}{|c|c|c|c|c|c|c|c|c|c|c|}
\hline \multirow{2}{*}{$\begin{array}{l}\text { Mineral } \\
\text { elemment }\end{array}$} & \multicolumn{3}{|c|}{ Leaves $^{\mathrm{a}}$} & \multicolumn{3}{|c|}{ Roots } & \multirow{2}{*}{ ANOVA } & \multirow{2}{*}{$\begin{array}{l}\text { Factor 1: } \\
\text { Site }\end{array}$} & \multirow{2}{*}{$\begin{array}{c}\text { Factor 2: } \\
\text { Organ }\end{array}$} & \multirow{2}{*}{$\begin{array}{c}\text { Interaction } \\
\text { Factor } 1 \times 2\end{array}$} \\
\hline & Site 1 & Site 2 & t-test & Site 1 & Site 2 & t-test & & & & \\
\hline $\begin{array}{l}\mathrm{Pb} \\
\left(\mu \mathrm{g} \cdot \mathrm{g}^{-1}\right)\end{array}$ & $\begin{array}{c}7.79 \\
(0.81)\end{array}$ & $\begin{array}{l}120.79 \\
(9.30)\end{array}$ & $* * *$ & $\begin{array}{c}3.40 \\
(0.52)\end{array}$ & $\begin{array}{l}34.94 \\
(5.58)\end{array}$ & $* * *$ & $\begin{array}{c}\mathrm{F} \\
\mathrm{p} \\
\text { significance }\end{array}$ & $\begin{array}{c}9.0093 \\
0.0049 \\
* *\end{array}$ & $\begin{array}{c}13.2330 \\
0.0009 \\
* * *\end{array}$ & $\begin{array}{c}36.3822 \\
0.0000 \\
* * *\end{array}$ \\
\hline $\begin{array}{l}\mathrm{Cr} \\
\left(\mu \mathrm{g} \cdot \mathrm{g}^{-1}\right)\end{array}$ & $\begin{array}{c}0.20 \\
(0.20)\end{array}$ & $\begin{array}{c}9.39 \\
(1.33)\end{array}$ & $* * *$ & $\begin{array}{c}9.79 \\
(1.56)\end{array}$ & $\begin{array}{c}7.19 \\
(0.80)\end{array}$ & ns & $\begin{array}{c}\mathrm{F} \\
\mathrm{p} \\
\text { significance }\end{array}$ & $\begin{array}{l}8.8428 \\
0.0052 \\
* *\end{array}$ & $\begin{array}{c}11.1659 \\
0.0020 \\
* *\end{array}$ & $\begin{array}{c}28.3899 \\
0.0000 \\
* * *\end{array}$ \\
\hline $\begin{array}{l}\text { Al } \\
\left(\mu g \cdot g^{-1}\right)\end{array}$ & $\begin{array}{l}561.20 \\
(43.48)\end{array}$ & $\begin{array}{l}2484.50 \\
(141.26)\end{array}$ & $* * *$ & $\begin{array}{l}2619.95 \\
(352.62)\end{array}$ & $\begin{array}{l}1974.78 \\
(187.45)\end{array}$ & $\mathrm{ns}$ & $\begin{array}{c}\mathrm{F} \\
\mathrm{p} \\
\text { significance }\end{array}$ & $\begin{array}{c}9.0093 \\
0.0049 \\
* *\end{array}$ & $\begin{array}{c}13.2330 \\
0.0009 \\
* * *\end{array}$ & $\begin{array}{c}36.3822 \\
0.0000 \\
* * *\end{array}$ \\
\hline $\begin{array}{l}\mathrm{Fe} \\
\left(\mu \mathrm{g} \cdot \mathrm{g}^{-1}\right)\end{array}$ & $\begin{array}{l}561.63 \\
(56.85)\end{array}$ & $\begin{array}{l}1949.60 \\
(133.01)\end{array}$ & $* * *$ & $\begin{array}{l}3360.07 \\
(384.10)\end{array}$ & $\begin{array}{l}1226.91 \\
(95.74)\end{array}$ & $* * *$ & $\begin{array}{c}\mathrm{F} \\
\mathrm{p} \\
\text { significance }\end{array}$ & $\begin{array}{c}3.1264 \\
0.0855 \\
\text { ns }\end{array}$ & $\begin{array}{c}24.2579 \\
0.0000 \\
* * *\end{array}$ & $\begin{array}{c}69.8020 \\
0.0000 \\
* * *\end{array}$ \\
\hline $\begin{array}{l}\mathrm{Cu} \\
\left(\mu \mathrm{g} \cdot \mathrm{g}^{-1}\right)\end{array}$ & $\begin{array}{c}6.59 \\
(0.73)\end{array}$ & $\begin{array}{l}19.37 \\
(0.67)\end{array}$ & $* * *$ & $\begin{array}{l}19.58 \\
(1.76)\end{array}$ & $\begin{array}{l}13.98 \\
(1.23)\end{array}$ & $*$ & $\begin{array}{c}\mathrm{F} \\
\mathrm{p} \\
\text { significance }\end{array}$ & $\begin{array}{c}9.1993 \\
0.0045 \\
* *\end{array}$ & $\begin{array}{c}10.3526 \\
0.0027 \\
* *\end{array}$ & $\begin{array}{c}60.5216 \\
0.0000 \\
* * *\end{array}$ \\
\hline $\begin{array}{l}\mathrm{Ni} \\
\left(\mu g \cdot g^{-1}\right)\end{array}$ & $\begin{array}{c}1.20 \\
(0.44)\end{array}$ & $\begin{array}{l}10.20 \\
(0.76)\end{array}$ & $* * *$ & $\begin{array}{l}11.20 \\
(0.74)\end{array}$ & $\begin{array}{c}7.20 \\
(0.61)\end{array}$ & $* * *$ & $\begin{array}{c}\mathrm{F} \\
\mathrm{p} \\
\text { significance }\end{array}$ & $\begin{array}{c}14.7638 \\
0.0005 \\
* * *\end{array}$ & $\begin{array}{c}28.9370 \\
0.0000 \\
* * *\end{array}$ & $\begin{array}{c}99.8031 \\
0.0000 \\
* * *\end{array}$ \\
\hline $\begin{array}{l}\mathrm{Mn} \\
\left(\mu \mathrm{g} \cdot \mathrm{g}^{-1}\right)\end{array}$ & $\begin{array}{l}49.20 \\
(4.16)\end{array}$ & $\begin{array}{l}62.10 \\
(4.01)\end{array}$ & $*$ & $\begin{array}{l}36.98 \\
(5.39)\end{array}$ & $\begin{array}{l}20.17 \\
(1.94)\end{array}$ & $* *$ & $\begin{array}{c}\mathrm{F} \\
\mathrm{p} \\
\text { significance }\end{array}$ & $\begin{array}{c}0.2277 \\
0.6363 \\
\text { ns }\end{array}$ & $\begin{array}{c}43.6736 \\
0.0000 \\
* * *\end{array}$ & $\begin{array}{c}13.1470 \\
0.0009 \\
* * *\end{array}$ \\
\hline $\begin{array}{l}\mathrm{Zn} \\
\left(\mu \mathrm{g} \cdot \mathrm{g}^{-1}\right)\end{array}$ & $\begin{array}{l}107.05 \\
(5.29)\end{array}$ & $\begin{array}{l}116.39 \\
(4.45)\end{array}$ & $\mathrm{ns}$ & $\begin{array}{l}51.55 \\
(2.28)\end{array}$ & $\begin{array}{l}83.44 \\
(3.48)\end{array}$ & $* * *$ & $\begin{array}{c}\mathrm{F} \\
\mathrm{p} \\
\text { significance }\end{array}$ & $\begin{array}{c}26.1164 \\
0.0000 \\
* * *\end{array}$ & $\begin{array}{c}120.2599 \\
0.0000 \\
* * *\end{array}$ & $\begin{array}{c}7.8123 \\
0.0083 \\
* *\end{array}$ \\
\hline $\begin{array}{l}\mathrm{N} \\
\left(\mathrm{mg} \cdot \mathrm{g}^{-1}\right)\end{array}$ & $\begin{array}{l}38.31 \\
(1.09)\end{array}$ & $\begin{array}{l}38.55 \\
(2.09)\end{array}$ & ns & $\begin{array}{c}8.45 \\
(0.39)\end{array}$ & $\begin{array}{l}13.89 \\
(0.88)\end{array}$ & $* * *$ & $\begin{array}{c}\mathrm{F} \\
\mathrm{p} \\
\text { significance }\end{array}$ & $\begin{array}{c}2.8241 \\
0.0986 \\
\text { ns }\end{array}$ & $\begin{array}{c}260.5296 \\
0.0000 \\
* * *\end{array}$ & $\begin{array}{c}2.3641 \\
0.1300 \\
\text { ns }\end{array}$ \\
\hline $\begin{array}{l}\mathrm{P} \\
\left(\mathrm{mg} \cdot \mathrm{g}^{-1}\right)\end{array}$ & $\begin{array}{c}2.33 \\
(0.15)\end{array}$ & $\begin{array}{c}6.38 \\
(0.39)\end{array}$ & $* * *$ & $\begin{array}{c}1.41 \\
(0.10)\end{array}$ & $\begin{array}{c}4.06 \\
(0.23)\end{array}$ & $* * *$ & $\begin{array}{c}\mathrm{F} \\
\mathrm{p} \\
\text { significance }\end{array}$ & $\begin{array}{c}5.4341 \\
0.0255 \\
*\end{array}$ & $\begin{array}{c}81.2202 \\
0.0000 \\
* * *\end{array}$ & $\begin{array}{c}34.6945 \\
0.0000 \\
* * *\end{array}$ \\
\hline $\begin{array}{l}\mathrm{K} \\
\left(\mathrm{mg} \cdot \mathrm{g}^{-1}\right)\end{array}$ & $\begin{array}{c}5.13 \\
(0.34)\end{array}$ & $\begin{array}{c}9.02 \\
(0.86)\end{array}$ & $* * *$ & $\begin{array}{c}3.86 \\
(0.17)\end{array}$ & $\begin{array}{c}8.01 \\
(0.61)\end{array}$ & $* * *$ & $\begin{array}{c}\mathrm{F} \\
\mathrm{p} \\
\text { significance }\end{array}$ & $\begin{array}{c}51.2518 \\
0.0000 \\
* * *\end{array}$ & $\begin{array}{c}4.0841 \\
0.0508 \\
\text { ns }\end{array}$ & $\begin{array}{c}0.0507 \\
0.8231 \\
\text { ns }\end{array}$ \\
\hline $\begin{array}{l}\mathrm{Ca} \\
\left(\mathrm{mg} \cdot \mathrm{g}^{-1}\right)\end{array}$ & $\begin{array}{l}22.20 \\
(0.67)\end{array}$ & $\begin{array}{l}28.11 \\
(1.57)\end{array}$ & $*$ & $\begin{array}{c}3.67 \\
(0.23)\end{array}$ & $\begin{array}{c}6.33 \\
(0.35)\end{array}$ & $* * *$ & $\begin{array}{c}\mathrm{F} \\
\mathrm{p} \\
\text { significance }\end{array}$ & $\begin{array}{c}14.4877 \\
0.0005 \\
* * *\end{array}$ & $\begin{array}{c}715.2939 \\
0.0000 \\
* * *\end{array}$ & $\begin{array}{c}0.9961 \\
0.3249 \\
\text { ns }\end{array}$ \\
\hline $\begin{array}{l}\mathrm{Mg} \\
\left(\mathrm{mg} \cdot \mathrm{g}^{-1}\right)\end{array}$ & $\begin{array}{c}6.83 \\
(0.40)\end{array}$ & $\begin{array}{c}4.46 \\
(0.30)\end{array}$ & $* * *$ & $\begin{array}{c}2.53 \\
(0.24)\end{array}$ & $\begin{array}{c}3.56 \\
(0.15)\end{array}$ & $* *$ & $\begin{array}{l}\mathrm{F} \\
\mathrm{p}\end{array}$ & $\begin{array}{l}5.4341 \\
0.0255\end{array}$ & $\begin{array}{c}81.2202 \\
0.0000\end{array}$ & $\begin{array}{c}34.6945 \\
0.0000\end{array}$ \\
\hline $\begin{array}{l}\text { Enzimatic activities } \\
\text { NRA } \\
\left(\mathrm{mmol} \cdot \mathrm{g}^{-1} \cdot \mathrm{h}^{-1}\right)\end{array}$ & $\begin{array}{l}2.50 \\
(0.54)\end{array}$ & $\begin{array}{c}1.03 \\
(0.42)\end{array}$ & $*$ & $\begin{array}{c}0.30 \\
(0.11)\end{array}$ & $\begin{array}{c}0.53 \\
(0.16)\end{array}$ & ns & $\begin{array}{c}\text { significance } \\
\mathrm{F} \\
\mathrm{p} \\
\text { significance }\end{array}$ & $\begin{array}{r}* \\
8.8428 \\
0.0052 \\
* *\end{array}$ & $\begin{array}{r}* * * \\
11.1659 \\
0.0020 \\
* *\end{array}$ & $\begin{array}{r}* * * \\
28.3899 \\
0.0000 \\
* * *\end{array}$ \\
\hline $\begin{array}{l}\text { APA } \\
\left(\mu \mathrm{mol} \cdot \mathrm{g}^{-1} \cdot \mathrm{min}^{-1}\right)\end{array}$ & $\begin{array}{c}0.44 \\
(0.04)\end{array}$ & $\begin{array}{c}0.77 \\
(0.06)\end{array}$ & $* *$ & $\begin{array}{c}0.07 \\
(0.02)\end{array}$ & $\begin{array}{c}0.24 \\
(0.06)\end{array}$ & $*$ & $\begin{array}{c}\mathrm{F} \\
\mathrm{p} \\
\text { significance }\end{array}$ & $\begin{array}{r}27.4349 \\
0.0001 \\
* * *\end{array}$ & $\begin{array}{r}89.5080 \\
0.0000 \\
* * *\end{array}$ & $\begin{array}{r}2.5823 \\
0.1276 \\
\text { ns }\end{array}$ \\
\hline
\end{tabular}

${ }^{a}$ Mean $(\mathrm{SE})(\mathrm{n}=5)$ expressed by dry mass. Statistically significant differences (t-test and two way ANOVA) between both sites and organs are denoted as: ns $=$ not significant, ${ }^{*} \mathrm{p}<0.5, * * \mathrm{p}<0.1, * * * \mathrm{p}<0.01$. 
Table 2. Chlorophyll content, chlorophyll $a / b$ ratio, carotenoids, UV-B absorbing compounds (flavonoids), total phenols, lipid peroxidation measured by the formation of a malondialdehyde (MDA)-2-thiobarbituric acid (TBA) complex, water-soluble proteins and specific leaf mass (SLM) in leaves of T. diversifolia from two sites: with light (1) or heavy (2) automotive traffic, with different foliar $\mathrm{Pb}$ concentrations (7.79 \pm 0.81 and $121.79 \pm 9.30$ respectively, see Table 1).

\begin{tabular}{|c|c|c|c|c|c|c|}
\hline Parameter & Site $1^{\mathrm{a}}$ & Site 2 & $\begin{array}{c}\text { Statistics } \\
\text { t-test }\end{array}$ & $\begin{array}{c}\text { ANOVA } \\
\text { F }\end{array}$ & $\mathrm{p}$ & significance \\
\hline $\begin{array}{l}\text { Chlorophyll } \\
\left(\mathrm{mg} \cdot \mathrm{g}^{-1}\right)\end{array}$ & $\begin{array}{c}9.32 \\
(1.18)\end{array}$ & $\begin{array}{c}9.11 \\
(0.66)\end{array}$ & ns & 0.0230 & 0.8832 & $\mathrm{~ns}$ \\
\hline Chl $a / b$ & $\begin{array}{c}3.58 \\
(0.09)\end{array}$ & $\begin{array}{c}3.40 \\
(0.08)\end{array}$ & ns & 2.0422 & 0.1908 & $\mathrm{~ns}$ \\
\hline $\begin{array}{l}\text { Carotenoids } \\
\left(\mathrm{mg} \cdot \mathrm{g}^{-1}\right)\end{array}$ & $\begin{array}{c}1.82 \\
(0.14)\end{array}$ & $\begin{array}{c}1.68 \\
(0.24)\end{array}$ & ns & 0.2659 & 0.6200 & ns \\
\hline $\begin{array}{l}\text { UV-B Absorb. } \\
\text { compounds } \\
\left(\Delta \mathrm{A}_{300} \cdot \mathrm{g}^{-1}\right)\end{array}$ & $\begin{array}{l}233.48 \\
(27.84)\end{array}$ & $\begin{array}{l}280.61 \\
(48.40)\end{array}$ & ns & 0.7126 & 0.4231 & $\mathrm{~ns}$ \\
\hline $\begin{array}{l}\text { Phenols } \\
\left(\mathrm{mg} \cdot \mathrm{g}^{-1}\right)\end{array}$ & $\begin{array}{c}6.72 \\
(0.63)\end{array}$ & $\begin{array}{c}8.82 \\
(0.59)\end{array}$ & * & 5.8766 & 0.0416 & * \\
\hline $\begin{array}{l}\text { MDA-TBA } \\
\text { complex } \\
(\text { nmol.g } \\
-1)\end{array}$ & $\begin{array}{l}203.37 \\
(23.30)\end{array}$ & $\begin{array}{c}187.57 \\
(9.68)\end{array}$ & $\mathrm{ns}$ & 0.3918 & 0.5488 & $\mathrm{~ns}$ \\
\hline $\begin{array}{l}\text { Water sol. } \\
\text { proteins } \\
\left(\mu \mathrm{g} \cdot \mathrm{g}^{-1}\right)\end{array}$ & $\begin{array}{l}431.30 \\
(43.60)\end{array}$ & $\begin{array}{l}491.27 \\
(29.08)\end{array}$ & $\mathrm{ns}$ & 1.3099 & 0.2855 & ns \\
\hline $\begin{array}{l}\text { SLM } \\
\left(\mathrm{mg} . \mathrm{cm}^{-2}\right)\end{array}$ & $\begin{array}{l}5.23 \\
(0.23)\end{array}$ & $\begin{array}{c}3.05 \\
(0.10)\end{array}$ & $* * *$ & 77.6470 & 0.0000 & $* * *$ \\
\hline
\end{tabular}

${ }^{\mathrm{a}}$ Mean $(\mathrm{SE})(\mathrm{n}=5)$ expressed by dry mass. Statistically significant differences (t-test and one way ANOVA) are denoted as: $\mathrm{ns}=$ not significant, ${ }^{*} \mathrm{p}<0.5,{ }^{* * *} \mathrm{p}<0.01$.

Table 3. Specific leaf mass (SLM) and lead content, total phenols and acid phosphatase activity (APA) in leaves and roots of T. diversifolia grown in pots without $(-\mathrm{Pb})$ or with $2 \mathrm{~g} \mathrm{~kg}^{-1} \mathrm{~Pb}$-acetate $(+\mathrm{Pb})$ after 34 days of the $\mathrm{Pb}$ application.

\begin{tabular}{|c|c|c|c|c|c|c|c|c|c|c|}
\hline \multirow{2}{*}{ Parameter } & \multicolumn{3}{|c|}{ Leaves $^{\mathrm{a}}$} & \multicolumn{3}{|c|}{ Roots } & \multirow{2}{*}{ ANOVA } & \multirow{2}{*}{$\begin{array}{l}\text { Factor 1: } \\
\text { Treatment }\end{array}$} & \multirow{2}{*}{$\begin{array}{c}\text { Factor 2: } \\
\text { Organ }\end{array}$} & \multirow{2}{*}{$\begin{array}{l}\text { Interaction } \\
\text { Factor } 1 \times 2\end{array}$} \\
\hline & $-\mathrm{Pb}$ & $+\mathrm{Pb}$ & t-test & $-\mathrm{Pb}$ & $+\mathrm{Pb}$ & t-test & & & & \\
\hline $\begin{array}{l}\mathrm{Pb} \\
\left(\mu g \cdot g^{-1}\right)\end{array}$ & $\begin{array}{c}1.43 \\
(0.36)\end{array}$ & $\begin{array}{l}19.48 \\
(6.26)\end{array}$ & $* *$ & $\begin{array}{l}38.37 \\
(4.52)\end{array}$ & $\begin{array}{l}2376.73 \\
(282.07)\end{array}$ & $* * *$ & $\begin{array}{c}\mathrm{F} \\
\mathrm{p} \\
\text { significance }\end{array}$ & $\begin{array}{c}61.9961 \\
0.0000 \\
* * *\end{array}$ & $\begin{array}{c}63.9998 \\
0.0000 \\
* * *\end{array}$ & $\begin{array}{c}60.1108 \\
0.0000 \\
* * *\end{array}$ \\
\hline $\begin{array}{l}\text { Phenols } \\
\left(\mathrm{mg} \cdot \mathrm{g}^{-1}\right)\end{array}$ & $\begin{array}{l}15.20 \\
(1.28)\end{array}$ & $\begin{array}{l}15.10 \\
(1.53)\end{array}$ & $\mathrm{ns}$ & $\begin{array}{c}4.64 \\
(0.43)\end{array}$ & $\begin{array}{c}9.18 \\
(0.54)\end{array}$ & $* * *$ & $\begin{array}{c}\mathrm{F} \\
\mathrm{p} \\
\text { significance }\end{array}$ & $\begin{array}{c}4.4318 \\
0.0514 \\
\text { ns }\end{array}$ & $\begin{array}{c}61.2956 \\
0.0000 \\
* * *\end{array}$ & $\begin{array}{c}4.8539 \\
0.0426 \\
*\end{array}$ \\
\hline $\begin{array}{l}\text { APA } \\
\left(\mu \mathrm{mol} \cdot \mathrm{g}^{-1} \cdot \mathrm{min}^{-1}\right)\end{array}$ & $\begin{array}{c}0.87 \\
(0.02)\end{array}$ & $\begin{array}{c}0.75 \\
(0.06)\end{array}$ & $*$ & $\begin{array}{c}0.63 \\
(0.04)\end{array}$ & $\begin{array}{c}0.68 \\
(0.02)\end{array}$ & $\mathrm{ns}$ & $\begin{array}{c}\mathrm{F} \\
\mathrm{p} \\
\text { significance }\end{array}$ & $\begin{array}{c}0.8650 \\
0.3662 \\
\text { ns }\end{array}$ & $\begin{array}{c}16.5802 \\
0.0009 \\
* * *\end{array}$ & $\begin{array}{c}4.3073 \\
0.0544 \\
\text { ns }\end{array}$ \\
\hline $\begin{array}{l}\text { SLM } \\
\left(\mathrm{mg} \cdot \mathrm{cm}^{-2}\right)\end{array}$ & $\begin{array}{l}3.05 \\
(0.19)\end{array}$ & $\begin{array}{l}3.13 \\
(0.14)\end{array}$ & ns & No aplicable & & & $\begin{array}{c}\mathrm{F} \\
\mathrm{p} \\
\text { significance }\end{array}$ & $\begin{array}{l}0.0920 \\
0.7694 \\
\text { ns }\end{array}$ & No aplicable & \\
\hline
\end{tabular}

${ }^{a}$ Mean (SE) $(n=5)$ expressed by dry mass. Statistically significant differences ( $\mathrm{t}$-test and ANOVA) are indicated: $\mathrm{ns}=\mathrm{not}$ significant, $* \mathrm{p}<0.5$, $* * \mathrm{p}<0.1, * * * \mathrm{p}<0.01$. 
heavy metals into plant tissues: soil uptake and the atmospheric deposition from settling dust (Fodor, 2002). On the other hand, similar concentrations of $\mathrm{Cr}, \mathrm{Al}, \mathrm{Fe}, \mathrm{Cu}$ and $\mathrm{Ni}$ were found in both organs at Site 2, while roots contained larger amounts of these metals than leaves collected at control Site 1. Usually, roots have a higher concentration of $\mathrm{Pb}$ than leaves (Wierzbicka, 1999). Higher metal concentrations in roots than in shoots are frequently observed in nonhyperaccumulator plants (McGrath et al., 2001). Generally the majority of $\mathrm{Pb}$ is attached to the cell walls in the roots and competes with $\mathrm{Ca}$ in the adsorption of cations by the carboxylic groups of the matrix substances, galacturonic and glucuronic acids. However, despite the retention of $\mathrm{Pb}$ in the root, there are plants in which a significant amount of the metal is transported to the shoot (Cseh, 2002).

Compartmentalization and sequestration with organic acids have been proposed as mechanisms of tolerance to metals in Asteraceae. In sunflower, trichomes play a role in the tolerance to Mn toxicity (Blamey et al., 1986).

T. diversifolia also possesses trichomes in the leaves but the compartmentalization of $\mathrm{Pb}$ in the organs was not evaluated in the present study. Nevertheless, the localization of metals in a metabolically inactive form in trichomes is a possible explanation for the unusually higher concentration of $\mathrm{Pb}$ found in leaves compared to roots of $T$. diversifolia field plants.

Although the leaves were washed, the hair and cuticle can trap contaminants. Metals, such as Fe and Al, can be used as markers for soil contamination in plant analyses. The metals with higher concentration in the leaves were $\mathrm{Al}, \mathrm{Fe}$ and $\mathrm{Cu}$ (table 1) and these were 3 or 4 times higher for the polluted site compared to Site 1 , whereas $\mathrm{Pb}$ was 15 times higher, indicating uptake of this metal.

In general, toxic metals may cause deficiency of other elements essential for plants (Fodor, 2002; Krupa et al., 2002). However, this was not observed in the data of table 1. At Site 2 agricultural and urban development is higher than for Site 1 , and consequently the input of nutrients through irrigation by streams is larger.

Enzymatic activities: The NRA in leaves diminished at the polluted site but no changes were observed in roots (table 1). Kłobus et al. (2002) showed different examples of inhibition of nitrate reductase in plants under heavy metal stress.

Singh et al. (1997) reported that nitrate reduction was inhibited drastically in roots by $\mathrm{Pb}$ but in leaves different effects have been observed with various cultivars. Leaf NRA in Vigna radiata increased with increasing $\mathrm{Pb}$ (Singh et al., 1997/98), while Kevresan et al. (2001) found a significant decrease in the NRA in the aboveground parts of young pea plants.

The APA increased at Site 2, where leaves had a higher concentration of $\mathrm{P}$. The exposure of roots to Ni markedly stimulated phosphatase activity in Alyssum bertolonii (Gabbrielli et al., 1989). The deposition of $\mathrm{Pb}$ pyrophosphate along cell walls was proposed as the main process responsible for $\mathrm{Pb}$ accumulation in root tissues. A favourable $\mathrm{P}$ regime reduces the effects of $\mathrm{Pb}$ toxicity, since $\mathrm{Pb}$ can form insoluble phosphates (Kabata Pendias and Pendias, 1984).

\section{Organic compounds affected by metals and leaf specific mass:}

Plants from Site 2 were exposed to daily traffic during their entire lifespan (long time exposure). The plant samples from the field analysed here did not produce responses such as depletion of chlorophyll, carotenoids and proteins, nor increases in lipid peroxidation, reported in the literature for leaves of plantlets under greenhouse conditions.

Changes of the foliar structure in response to $\mathrm{Pb}$ have been reported by Kovačević et al. (1999), who found smaller lamina and mesophyll thickness, epidermal cell size and diameter of vessels. Differences in SLM, related to leaf thickness, were expected for both sites. Detoxification through phenols was also expected (Giertych et al., 1999).

An increase in phenol concentration and a highly significant drop in SLM was observed in Site 2 (table 2). However, phenol concentration in leaves and SLM were not affected, in spite of a significant increase (13.6 times) in foliar $\mathrm{Pb}$ observed between the treatments in the pot experiment (see below). On the other hand, $\mathrm{Pb}$ concentration in contaminated leaves in the field (table 1) was 6 times higher than in the $+\mathrm{Pb}$ treatment in the pot experiment (table 3 ) presumably because there was an input of $\mathrm{Pb}$ from the air due to the traffic, absent in the pot experiment.

Pot experiment with Pb-supplemented soil: APA of roots was not affected when comparing both treatments despite the $\mathrm{Pb}$ concentration being different by a factor of 62 . In leaves a decrease of activity was observed. According to these result the increase of APA observed in the field for contaminated plants is probably not a response to $\mathrm{Pb}$ concentration. In this experiment plants were grown in the same soil with or without the $\mathrm{Pb}$ supplement.

The highly significant increase of phenols in response to $\mathrm{Pb}$ observed for roots has been reported by several authors for other plants in response to metals. 
Ruso et al. (2001) found a good correlation between the induced synthesis of phenols, mainly in root tissue, and the tolerance and accumulation of heavy metals in sunflower. It was proposed the selection of lines for their constitutive and induced phenol content to be used for phytoremediation.

Giertych et al. (1999) found higher phenol contents in plants at a polluted site compared with a control site. Total phenols include condensed and hydrolysable tannins, flavonoids, phenolic glucosides and chlorogenic acids. The hydroxyl radicals of tannins have a strong affinity for metals and are used in industry as metal chelators. For example, the high concentrations of tannins in Psychotria douarrei leaves might function as a detoxification mechanism for elevated cytoplasmic metal concentrations, in addition to providing defensive benefits (Davis et al., 2001). Lavid et al. (2001 a,b) demonstrated the involvement of phenols in Cd accumulation in aquatic plants. Polyphenols in Nymphaea chelate $\mathrm{Pb}$, $\mathrm{Cr}$ and $\mathrm{Hg}$ in vitro (Lavid et al., 2001b). The phenolics are generally thought to prevent oxidative damage by scavenging active oxygen species and by breaking the radical chain reactions during lipid peroxidation. These antioxidative effects require the reduced form of phenolics. In the oxidized form (unstable under physiological conditions but stabilized by Al) act as prooxidants (Sakihama and Yamasaki, 2002).

As a conclusion T. diversifola growing wild on roadsides with heavy urban traffic presented levels of $\mathrm{Pb}$ in leaves and roots considered as typical of contaminated plants, but without visible symptoms of damage to the leaves or depletion of chlorophyll, carotenoids, proteins nor increases in lipid peroxidation. These are responses reported in the literature for plants under $\mathrm{Pb}$ stress. On the other hand, phenols increased and this was also observed in roots with high $\mathrm{Pb}$ concentration after $\mathrm{Pb}$-acetate application. The identification and role of phenols in the tolerance to $\mathrm{Pb}$ in this species deserves the attention of future research.

Acknowledgements: The author thanks Eder Peña for carrying out statistical and mineral analyses. Guillermina Aguiar performed the measurements with the atomic absorption spectrophotometer. This work was partially sponsored by CONICIT, project S1-98003716.

\section{REFERENCES}

Amorim HV, Dougall DK, Sharp WR (1977) The effect of carbohydrate and nitrogen concentration on phenol synthesis in Paul's Scarlet Rose cells grown in tissue culture. Physiol. Plant. 39:91-95.

Ayeni AO, Loordbanjou DT, Majek BA (1997) Tithonia diversifolia (Mexican sunflower) in South-western Nigeria: Occurrence and growth habit. Weed Res. 37:443-449.
Baryla A, Laborde C, Montillet JL, Triantaphylidès C, Chagvardieff P (2000) Evaluation of lipid peroxidation as a toxicity bioassay for plants exposed to copper. Environ. Pollut. 109:131-135.

Blamey FPC, Joyce DC, Edwards DG, Asher CJ (1986) Role of trichomes in sunflower tolerance to manganese toxicity. Plant Soil 91:171-180.

Bradford MM (1976) A rapid and sensitive method for the quantitation of microgram quantities of protein utilizing the principle of protein-dye binding. Anal. Biochem. $72: 248-254$.

Cakmak I, Horst WJ (1991) Effect of aluminium on lipid peroxidation, superoxide dismutase, catalase, and peroxidase activities in root tips of soybean (Glycine max). Physiol. Plant. 83:463-468.

Cseh E (2002) Metal permeability, transport and efflux in plants. In: Prasad MNV, Strzałka K (eds), Physiology and Biochemistry of Metal Toxicity and Tolerance in Plants, pp.1-36. Kluwer Academic Publishers, Dordrecht, The Netherlands.

Davis MA, Pritchard SG, Boyd RS, Prior SA (2001) Developmental and induced responses of nickel-based and organic defences of the nickel-hyperaccumulating shrub, Psichotria douarrei. New Phytol. 150:49-58.

Day TA, Demchik SM (1996) Influence of enhanced UV-B radiation on biomass allocation and pigment concentrations in leaves and reproductive structures of greenhousegrown Brassica rapa. Vegetatio 127:109-116.

Escalona L, Sanhueza E (1981) Elemental analysis of the total suspended matter in the air in downtown Caracas. Atmospheric Environ. 15:61-64.

Ewais EA (1997) Effects of cadmium, nickel and lead on growth, chlorophyll content and proteins of weeds. Biol. Plant. 39:403-410.

Fargašová A (2001) Phytotoxic effects of $\mathrm{Cd}, \mathrm{Zn}, \mathrm{Pb}, \mathrm{Cu}$ and Fe on Sinapis alba L. seedlings and their accumulation in roots and shoots. Biol. Plant. 44:471-473.

Fodor F (2002) Physiological responses of vascular plants to heavy metals. In: Prasad MNV, Strzałka K (eds), Physiology and Biochemistry of Metal Toxicity and Tolerance in Plants, pp.149-177. Kluwer Academic Publishers, Dordrecht, The Netherlands.

Gallego SM, Benavides MP, Tomaro ML (1999) Effect of cadmium ions on antioxidant defense system in sunflower cotyledons. Biol. Plant. 42:49-55.

García-Miragaya J, Castro S, Paolini J (1981) Lead and zinc levels and chemical fractionation in road-side soils of Caracas, Venezuela. Water Air Soil Pollut. 15:285-297.

George TS, Gregory PJ, Robinson JS, Buresh RJ, Jama B (2002 a) Utilisation of soil organic $P$ by agroforestry and crop species in the field, western Kenya. Plant Soil 246:53-63.

George TS, Gregory TJ, Robinson JS, Buresh RJ (2002 b) Changes in phosphorus concentrations and $\mathrm{pH}$ in the rhizosphere of some agroforestry and crop species. Plant Soil 246:65-73. 
Gabbrielli R, Grosi L, Vergnano O (1989) The effects of nickel, calcium and magnesium on the acid phosphatase activity of two Alyssum species. New Phytol. 111:631-636.

Giertych MJ, Karolewski P, De Temmerman LO (1999) Foliage age and pollution alter content of phenolic compounds and chemical elements in Pinus nigra needles. Water Air Soil Pollut. 110:363-377.

Han FX, Banin A, Su Y, Monts DL, Plodinec MJ, Kingery WL, Triplett GE (2002) Industrial age anthropogenic inputs of heavy metals into the pedosphere. Naturwissenschaften 89:497-504.

Hartley-Whitaker J, Ainsworth G, Meharg AA (2001) Copper- and arsenate-induced oxidative stress in Holcus lanatus L. clones with differential sensitivity. Plant Cell Environ. 24:713-722.

Hose GC, James JM, Gray MR (2002) Spider webs as environmental indicators. Environ. Pollut. 120:725-733.

Isermann K (1977) A method to reduce contamination and uptake of lead by plants from car exhaust gases. Environ. Pollut. 12:199-203.

Kabata-Pendias A, Pendias H (1984) Trace Elements in Soils and Plants. CRC Press, Boca Raton, U.S.A.

Kastori R, Plesničar M, Sakač Z, Pancović D, Arsenijević Maksimović I (1998) Effect of excess lead on sunflower growth and photosynthesis. J. Plant Nutr. 21:75-85.

Kevresan S, Petrovic N, Popovic M, Kandrac J (2001) Nitrogen and protein metabolism in young pea plants as affected by different concentrations of nickel, cadmium, lead, and molybdenum. J. Plant Nutr. 24:1633-1644.

Kłobus G, Burzynsky M, Buczek J (2002) Heavy metals and nitrogen metabolism. In: Prasad MNV, Strzałka K (eds), Physiology and Biochemistry of Metal Toxicity and Tolerance in Plants, pp.325-355. Kluwer Academic Publishers, Dordrecht, The Netherlands.

Kovačević G, Kastori R, Merkulov LJ (1999) Dry matter and leaf structure in young wheat plants as affected by cadmium, lead, and nickel. Biol. Plant. 42:119-123.

Krupa Z, Siedlecka A, Skórzynska-Polit E, Maksymiec W (2002) Heavy metal interactions with plant nutrients. In: Prasad MNV, StrzaBka K (eds), Physiology and Biochemistry of Metal Toxicity and Tolerance in Plants, pp.287301. Kluwer Academic Publishers, Dordrecht, The Netherlands.

Lagerwerff JV, Specht AW (1970) Contamination of roadside soil and vegetation with cadmium, nickel, lead, and zinc. Environ. Sci. Technol. 4:583-586.

Lavid N, Schwartz A, Lewinsohn E, Tel-Or E (2001 a) Phenols and phenol oxidases are involved in cadmium accumulation in the water plants Nymphoides peltata (Menyanthaceae) and Nymphaeae (Nymphaeaceae). Planta 214:189-195.

Lavid N, Schwartz A, Yarden O, Tel-Or E (2001 b) The involvement of polyphenols and peroxidase activities in heavy-metal accumulation by epidermal glands of the waterlily (Nymphaeaceae). Planta 212:323-331.
Lichtenthaler HK, Wellburn AR (1983) Determinations of total carotenoids and chlorophylls $a$ and $b$ of leaf extracts in different solvents. Biochem. Soc. Transactions 11:591-592.

Lindblad P, Guerrero MG (1993) Nitrogen fixation and nitrate reduction. In: Hall DO, Scurlock JMO, BolharNordenkampf HR, Leegood RC, Long SP (eds), Photosynthesis and Production in a Changing Environment: a Field and Laboratory Manual, pp. 299-312. Chapman and Hall, London, UK.

Lummerzheim M, Sandroni M, Castresana C, De Oliveira D, van Montagu M, Roby D, Timmerman B (1995) Comparative microscopic and enzymatic characterization of the leaf necrosis induced in Arabidopsis thaliana by lead nitrate and by Xanthomonas campestris pv. campestris after foliar spray. Plant Cell Environ. 18:499-509.

McGrath SP, Zhao FJ, Lombi E (2001) Plant and rhizosphere processes involved in phytoremediation of metal-contaminated soils. Plant Soil 232:207-214.

Medina E, García V, Cuevas E (1990) Sclerophylly and oligotrophic environments: relationships between leaf structure, mineral nutrient content, and drought resistance in tropical rain forests of the upper rio Negro region. Biotropica 22:51-64.

Mengel K, Kirkby E (2001) Principles of Plant Nutrition. Kluwer Academic Publishers, Dordrecht, The Netherlands.

Miller RO (1998) Nitric-perchloric acid wet digestion in an open vessel. In: Kalra YP (ed), Handbook of Reference Methods for Plant Analysis, pp.57-61. CRC Press, Boca Raton, U.S.A.

Motto HL, Daines RH, Chilko DM, Motto CK (1970) Lead in soils and plants: its relationship to traffic volume and proximity to highways. Environ. Sci. Technol. 4:231-237.

Murphy J, Riley J (1962) A modified single solution method for determination of phosphate in natural waters. Anal. Chem. Acta 27:31-36.

Olivares E, Peña E, Aguiar G (2002a) Nutrición mineral y estrés oxidativo por metales en espinaca y lechuga, en comparación con dos malezas asociadas, en cultivo semi-urbanos. Interciencia 27:454-464.

Olivares E, Peña E, Aguiar G (2002b) Metals and oxalate in Tithonia diversifolia (Asteraceae): concentrations in plants growing in contrasting soils, and $\mathrm{Al}$ induction of oxalate exudation by roots. J. Plant Physiol. 159:743-749.

Pereira PH, Cambraia J, Sant'Anna R, Mosquim PR, Moreira MA (1999) Aluminum effects on lipid peroxidation and on the activities of enzymes of oxidative metabolism in sorghum. Rev. Bras. Fisiol. Veg. 11:137-143.

Rios CI (1999) Tithonia diversifolia una planta con potencial para la producción sostenible en el trópico. In: Sánchez MD, Rosales M (eds), Agroforestería para la Producción Animal en América Latina. Estudio FAO Producción y Sanidad Animal 143, pp. 311-325. Roma, Italy.

Ross SM (1994) Sources and forms of potentially toxic metals in soil-plant systems. In: Ross SM (ed), Toxic Metals in Soil-Plant System, pp.3-25. John Wiley and Sons, Chichester, UK. 
Ruso J, Zapata J, Hernández M, Ojeda MA, Benlloch M, Prats-Pérez E, Tena M, López-Valbuena R, Jorrin JV (2001) Toxic metals accumulation and total soluble phenolics in sunflower and tobacco plants. Minerva Biotecnol.13:93-95.

Sakihama Y, Yamasaki H (2002) Lipid peroxidation induced by phenolics in conjunction with aluminium ions. Biol. Plant. 45:249-254.

Sandalio, LM, Dalurzo HC, Gómez M, Romero-Puertas MC, del Río LA (2001) Cadmium-induced changes in the growth and oxidative metabolism of pea plants. J. Exp. Bot. 52:2115-2126.

Shah K, Kumar RG, Verma S, Dubey RS (2001) Effect of cadmium on lipid peroxidation, superoxide anion generation and activities of antioxidant enzymes in growing rice seedlings. Plant Sci. 161:1135-1144.

Singh RP, Dabas S, Choudhary A, Maheshwari R (1997/98) Effect of lead on nitrate reductase activity and alleviation of lead toxicity by inorganic salts and 6-benzylaminopurine. Biol. Plant. 40:399-404.

Singh RP, Tripathi RD, Sinha SK, Maheshwari R, Srivastava HS (1997) Response of higher plants to lead contaminated environment. Chemosphere 34:2467-2493.
Suarez N (2000) Mecanismos de regulación salina bajo condiciones constantes y fluctuantes de salinidad en Avicennia germinans L. Caracas, Instituto Venezolano de Investigaciones Científicas. PhD thesis

Tabatabai MA, Bremner JM (1969) Use of p-nitrophenylphosphate for assay of soil phosphatase activity. Soil Biol. Biochem.1:301-307.

van Hasselt PR, Chow WS, Anderson JM (1996) Short-term treatment of pea leaves with supplementary UV-B at different oxygen concentrations: impacts on chloroplast and plasma membrane bound processes. Plant Sci. 120:1-9.

Ward NI, Reeves RD, Brooks RR (1975) Lead in soil and vegetation along a New Zealand state highway with low traffic volume. Environ. Pollut. 9:243-351.

Weiss D, Shotyk W, Kempf O (1999) Archives of atmospheric lead pollution. Naturwissenschaften 86:262-275.

Wierzbicka M (1999) Comparison of lead tolerance in $\mathrm{Al}$ lium cepa with other plant species. Environ. Pollut. 104:41-52.

Xiong ZT (1997) Bioaccumulation and physiological effects of excess lead in a roadside pioneer species Sonchus oleraceus L. Environ. Pollut. 97:275-279.

Yassoglou N, Kosmas C, Asimakopolus J, Kallianou C (1987) Heavy metal contamination of roadside soils in the Greater Athens area. Environ. Pollut. 47:293-304. 